\title{
Unsaturated fatty acid as functional food for the treatment of Diabetes mellitus type 2
}

\author{
Ácidos graxos insaturados como alimento funcional para o tratamento de Diabetes mellitus Tipo 2 \\ Ácidos grasos insaturados como alimento funcional para el tratamiento de la Diabetes mellitus tipo 2
}

Received: 06/16/2021 | Reviewed: 06/24/2021 | Accept: 07/22/2021 | Published: 07/29/2021

\author{
Naiane Silva Cardoso \\ ORCID: https://orcid.org/0000-0002-5254-4427 \\ Federal University of Alfenas, Brazil \\ E-mail: naicardoso@outlook.com \\ Júlia Rosental de Souza Cruz \\ ORCID: https://orcid.org/0000-0002-5004-244X \\ Federal University of Alfenas, Brazil \\ E-mail: jrosentalcruz@hotmail.com \\ Ramon Alves de Oliveira Paula \\ ORCID: https://orcid.org/0000-0002-4562-0970 \\ Federal University of Minas Gerais, Brazil \\ E-mail: alvesfarmacia@yahoo.com.br \\ Stella Maris da Silveira Duarte \\ ORCID: https://orcid.org/0000-0002-6276-3420 \\ Federal University of Alfenas, Brazil \\ E-mail: stellaunifal@yahoo.com.br \\ Maria Rita Rodrigues \\ ORCID: https://orcid.org/0000-0003-0940-002X \\ Federal University of Alfenas, Brazil \\ E-mail: maria.ritarodrigues@unifal-mg.edu.br \\ Fernanda Borges de Araújo Paula \\ ORCID: https://orcid.org/0000-0003-3077-3023 \\ Federal University of Alfenas, Brazil \\ E-mail: fernanda.paula@unifal-mg.edu.br
}

\begin{abstract}
Several studies have been demonstrating to a relationship between unsaturated fatty acids, improvement of pancreatic function and insulin secretion. In this context, this review presents the most recent findings on the pathophysiology of type 2 diabetes mellitus, the action mechanism of unsaturated fatty acids on pancreatic function, and clinical studies in diabetic patients. We evaluated here articles from MedLine/PubMed and the Science direct database, published between 2014 and 2020. Of the 637 results, 13 were selected. From their analysis, we could observe that mono and polyunsaturated fatty acids can improve glycemic control as well as reduce cardiovascular risk. The most recurrent antidiabetic action regarding monounsaturated fatty acids is the ability to preserve insulin signaling, whereas polyunsaturated fatty acids action consists in the increasing expression of the type 4 glucose transporter. However, a complete understanding of the relationship between fatty acids, insulin and inflammation should be considered in future investigations.
\end{abstract}

Keywords: Monounsaturated fatty acids; Bioactive compounds; Functional properties; Insulin resistance; Type 4 glucose transporter.

\section{Resumo}

Diversas pesquisas apontam para uma relação entre ácidos graxos insaturados, melhora da função pancreática e secreção de insulina. Nesse contexto, esta revisão apresenta os achados mais recentes sobre a fisiopatologia do diabetes mellitus tipo 2, o mecanismo de ação dos ácidos graxos insaturados na função pancreática e os estudos clínicos em pacientes diabéticos. Avaliamos aqui artigos do MedLine/PubMed e da base de dados Science direct, publicados entre 2014 e 2020. Dos 637 resultados, 13 foram selecionados. A partir da sua análise, observamos evidências de que ácidos graxos mono e poliinsaturados podem melhorar o controle glicêmico, bem como reduzir o risco cardiovascular. A ação antidiabética mais citada na literatura quanto aos ácidos graxos monoinsaturados é a capacidade de preservação da sinalização da insulina; já a dos ácidos graxos poliinsaturados consiste no aumento da expressão do transportador de glicose tipo 4. Entretanto, a compreensão completa da relação entre ácidos graxos, insulina e inflamação deve ser considerada em investigações futuras.

Palavras-chave: Ácidos graxos monoinsaturados; Compostos bioativos; Propriedades funcionais; Resistência à insulina; Transportador de glicose tipo 4. 


\section{Resumen}

Varios estudios apuntan a una relación entre los ácidos grasos insaturados, la función pancreática mejorada y la secreción de insulina. En este contexto, esta revisión presenta los hallazgos más recientes sobre la fisiopatología de la diabetes mellitus tipo 2, el mecanismo de acción de los ácidos grasos insaturados sobre la función pancreática y los estudios clínicos en pacientes diabéticos. Aquí evaluamos artículos de MedLine/PubMed y la base de datos directa de Science, publicados entre 2014 y 2020. De los 637 resultados, se seleccionaron 13. A partir de su análisis, vemos evidencia de que los ácidos grasos mono y poliinsaturados pueden mejorar el control glucémico y reducir el riesgo cardiovascular. La acción antidiabética más citada en la literatura con respecto a los ácidos grasos monoinsaturados es la capacidad de preservar la señalización de la insulina; por otro lado, el de los ácidos grasos poliinsaturados consiste en un aumento de la expresión del transportador de glucosa tipo 4. Sin embargo, en futuras investigaciones se debe considerar una comprensión completa de la relación entre los ácidos grasos, la insulina y la inflamación.

Palabras clave: Ácidos grasos monoinsaturados; Compuestos bioactivos; Propiedades funcionales; Resistencia a la insulina; Transportador de glucosa tipo 4.

\section{Introduction}

Diabetes mellitus is a group of metabolic disorders, characterized by hyperglycemia, probably caused by defects in insulin action and insulin secretion. Type 2 diabetes mellitus is the most common form of the disease, as insulin resistance is its main clinical feature (American Diabetes Association [ADA], 2020).

The global prevalence of type 2 diabetes has increased in recent years (Chen, Magliano, \& Zimmet, 2011; Chen, Gnanaraj, Arulselvan, El-Seedi, \& Teng, 2019; Saeedi et al., 2019). Projections report that it will reach in 2030, 578 million individuals; and in 2045, 700 million, predominantly from urban areas and high-income countries (Saeedi et al., 2019). In this context, Brazil presented, in 2017, 8.7 million individuals, aged between 20 and 79, with diabetes (World Health Assembly [WHA], 2013). These data show the importance of public policies and resources for research in the area. A multidisciplinary health team composed by physicians, pharmacists and nutritionists should also be considered (Tan et al., 2019).

Recent studies have found a relationship between unsaturated fatty acids, improvement of pancreatic function, and insulin secretion (Baynes, Mideksa \& Ambachew, 2018).

Fatty acids derive from hydrocarbons, belonging to the group of carboxylic acids and they have from 4 to 36 carbons in their length. According to the number of double bonds in the carbon chain they are classified as saturated, monounsaturated fatty acids (MUFA) or polyunsaturated fatty acids (PUFA) (Kaur, Chugh, \& Gupta, 2014).

Essential fatty acids are not synthesized by the body, so foods containing such fats must be part of our diet, such as $\alpha$ linolenic acid (omega 3, $\omega-3, \mathrm{C} 18: 3$ ) and linoleic acid (omega 6, $-6, \mathrm{C} 18: 2$ ). Furthermore, linolenic acid is a precursor to eicosapentaenoic acid (EPA) and docosahexaenoic acid (DHA), involved in fundamental biologic activities, such as modulating the inflammatory and immune response. Fatty acids, mostly, EPA and DHA interact directly with the structure of the cell membrane, activating or suppressing signaling molecules which will later interact directly with DNA and other proteins that affect transcription factors (Cagen et al., 2005; Erkkilä, Lichtenstein, Mozaffarian, \& Herrington, 2004; Kaur et al., 2014).

Nutritional therapy is one of the cornerstones of type 2 diabetes treatment, as its main objectives are glycemic control and weight loss. Flaxseed, sunflower seed, nuts, and fish oil are rich sources of linoleic acid, EPA and DHA. According to the most recent findings, regular consumption of omega 3 and omega 6 is highly recommended to reduce the risk of developing cardiovascular disease. Studies have also demonstrated a strong beneficial correlation between polyunsaturated fatty acids intake and a lower prevalence of diseases such as cancer, diabetes, and neurodegenerative diseases (Kaur et al., 2014; Zierath, 2019).

Considering that chronic non-communicable diseases are the main causes of disability and death worldwide, including diabetes, responsible for 1.6 million deaths/year (World Health Organization [WHO], 2018); as well as a progressive increase in these mortality rates in many countries, special attention and a careful approach must be given to them (WHO, 2020). 
This is a review of the most recent findings on pathophysiology of Diabetes, the mechanism of action of unsaturated fatty acids on pancreatic function and clinical studies in diabetic patients.

\section{Methodology}

This literature review was elaborated based on the question: "What are the latest findings regarding polyunsaturated fatty acids metabolism and type 2 diabetes?". In order to do so, the authors have chosen to focus on previous works that were central and essential to the topic. The study was conducted by assessing papers at MedLine/PubMed and Science direct database, which have been published from 2014 to 2020. The descriptors (MeSH Terms), combinations and search terms entered were: "Diabetes Mellitus Type 2"; "Nutrition Therapy"; "Polyunsaturated Fatty Acids"; "Monounsaturated and Polyunsaturated Fat Diet and Diabetes"; "Effect of monounsaturated and polyunsaturated acids in diabetes." The inclusion criteria were experimental and clinical papers published in English, Spanish, and Portuguese which the title and abstract suited the scopus of this review. The initial searched yielded a total of 637 results. The papers were screened by all three authors to determine their relevance. A paper selection was based on its research design, methods and results, so that only high-quality scientific studies would be considered to take part in this review. After data analysis, 13 papers were selected for this review. Lastly, the evidences extracted from the included studies were summarized and organized. The studies used in this review are briefly described at Table 1.

\section{Results and Discussion}

Table 1. Quick review of the studies analyzed on this paper.

\begin{tabular}{|c|c|}
\hline Authors & Highlighted findings \\
\hline Zong et $a l$. (2019) & $\begin{array}{l}\text { Prospective cohort study. Linoleic acid intake is related to diminished risk of developing type } 2 \\
\text { diabetes. Limitation: Only health care professionals were included. }\end{array}$ \\
\hline $\begin{array}{l}\text { Lenighan, McNulty, \& Roche } \\
\text { (2019) }\end{array}$ & $\begin{array}{l}\text { Qualitative review of } 46 \text { randomized clinical trials and prospective cohorts. Findings suggests that } \\
\text { PUFAs intake might reduce cardiovascular risk and improve glycemic control. }\end{array}$ \\
\hline Fuller et al. (2018) & $\begin{array}{l}\text { Randomized weight-loss controlled clinical trial. } \\
\text { High egg intake is not associated to an increase in cardiovascular risk. Limitation: evaluated the risk } \\
\text { factors for cardiovascular disease, which are weak predictors when compared to the real risk. }\end{array}$ \\
\hline Fayh et al. (2018) & $\begin{array}{l}\text { Randomized double-blinded study on physical activity and PUFA supplementation. There was no } \\
\text { significant difference in the biomarkers between treated and placebo groups. } \\
\text { Limitation: small sized sample and short period study. }\end{array}$ \\
\hline $\begin{array}{l}\text { Palomer, } \\
\text { Pizarro-Delgado, } \\
\text { Barroso, \& } \\
\text { Vázquez-Carrera (2018) }\end{array}$ & $\begin{array}{l}\text { A review paper showing that the replacement of SFA for oleic acid improves insulin sensitivity in } \\
\text { humans, and it addresses the molecular mechanisms by which oleic acid prevents palmitic acid- } \\
\text { induced inflammation and insulin resistance in adipose tissue, liver, skeletal muscle, and pancreas. }\end{array}$ \\
\hline Wanders et al. (2017) & $\begin{array}{l}\text { Cross-sectional study. Diabetic participants in the Netherlands Epidemiology of Obesity (NEO) study. } \\
\text { The findings suggest that the relationship between fatty acids and risk markers for type } 2 \text { diabetes } \\
\text { depends on dietary sources of fatty acids. }\end{array}$ \\
\hline $\begin{array}{l}\text { Keapai, Apichai, Amornlerdpison, } \\
\text { \& Lailerd (2016) }\end{array}$ & $\begin{array}{l}\text { Experimental study using diabetic Wistar rats, treated with fish oil rich in MUFA. The findings show } \\
\text { that fish oil supplementation improved glucose tolerance, insulin sensitivity, and pancreatic } \\
\text { histological changes in the animals. The performance of the oil was to increase the phosphorylation of } \\
\text { p-Akt Ser473 and p-PKC- } \zeta / \lambda \text { Thr410/403), as to increase the expression of GLUT4 membrane } \\
\text { proteins. }\end{array}$ \\
\hline $\begin{array}{l}\text { Wang, He, Yu, Jin, Gong, \& } \\
\text { Zhang (2020) }\end{array}$ & $\begin{array}{l}\text { Experimental study using C57BL/6J and KKay mice with type } 2 \text { diabetes treated with Perila oil rich in } \\
\text { unsaturated fats. Oil treatment increased the expression of PI3K/protein kinase B (AKT) and activated } \\
\text { the expression of Glut } 4 \text { transporter and phosphorus-AKT serine/ threonine kinase (p-AS160) in the } \\
\text { liver. }\end{array}$ \\
\hline Liu et al. (2020) & $\begin{array}{l}\text { Experimental study using C57BL } / 6 \text { mice, treated with a diet of different proportions of } \omega-3 / \omega-6 \text {. The } \\
\text { results show that } \omega-3 \text { was able to prevent metabolic syndrome, by regulating the mTORC } 1 \text { pathway, in } \\
\text { addition to increasing the activities of mitochondrial complexes. }\end{array}$ \\
\hline
\end{tabular}


Santos \& Fleming (2020)

Paquet, Propsting, \& Daniel (2014)

Jaganathan, Ravindran, \&

Dhanasekaran (2018)

Mirmiran, Esfandyari, Moghadam, Bahadoran, \& Azizi (2018)
Literature review focusing on the metabolism of PUFA by cytochrome P450 enzymes, and consequent generation of bioactive metabolites. These metabolites have anti-inflammatory activities and improve insulin sensitivity.

Observational study aimed to investigate the relationship of total n-3 fatty acids and SFA intake with insulin resistance. Volunteers at high risk for diabetes composed the sample group, where the 3-day dietary records were collected, and blood tests were performed to assess insulin resistance (glucose, HOMA-IR, OGTT, insulin and lipid profile). The study emphasizes that SFAs promote insulin resistance and $n-3$ s have a protective role.

Literature review on the different functions of hormones secreted by adipose tissue. The findings indicate significant functions of adipocytokines in regulating glucose and lipid metabolism, having an anti-inflammatory function and regulatory roles in diabetes.

Prospective study assessed the relationship between quantity and quality of fatty acids to the risk of developing type 2 diabetes in adults. Blood sample and dietary data from 2,139 adults were collected. The results obtained show that diets rich in cholesterol, monounsaturated, polyunsaturated, and $\omega-3$ fatty acids are associated with a lower risk of type 2 diabetes. Furthermore, $\omega-6 / \omega-3$ and total fat $/ \omega-3$ ratios were positively associated with type 2 diabetes.

Source: Authors.

\section{Action mechanism of MUFA}

Explaining briefly, the insulin signaling pathway starts when this hormone binds to its receptor, leading to phosphorylation of the insulin receptor tyrosine kinase and insulin receptor substrate (IRS) proteins and recruitment of phosphatidylinositol 3-kinase (PI3K). The PI3K, in turn, activates the protein kinase Akt, controlling the translocation of the glucose transporter type 4 (GLUT4) to the membranes (Huang \& Czech, 2007; Keapai et al., 2016).

In muscle cells, the insulin signaling through the PI3K pathway with the presence of high intracellular calcium levels - resulting from muscle contraction - leads to the activation of downstream proteins, such as the threonine of the atypical protein kinase $\mathrm{C}-\zeta / \lambda(\mathrm{aPKC}-\zeta / \lambda$ ), and the 5 ' adenosine monophosphate-activated protein kinase (AMPK), these phosphorylate effectors that modulate GLUT4 traffic (Huang \& Czech, 2007).

In order to assess the action of fish oil rich in MUFA on the insulin signaling pathway, Kaepai et al. observed an increase in AKT phosphorylation (Ser473), PKC- $/ / \lambda^{\text {Thr } 410 / 403}$ and AMPK in the skeletal muscle of treated diabetic animals compared to untreated animals, while AKT protein expression did not differ in all experimental groups. The same was observed in the expression of GLUT4, indicating that the antidiabetic effect of the oil is due to the activation of AMPK, preserving normal insulin signaling (Keapai et al., 2016).

Mediterranean diets have, as a standard, a low intake of saturated fatty acids (SFA) and high intakes of MUFA, and these fats originate from vegetable sources (Salas-Salvadó et al., 2014). Among MUFA, oleic acid stands out by contributing differently to insulin resistance, it acts against the inflammatory process, decreasing the expression of pro-inflammatory cytokines and acting on hepatocytes, increasing the peroxisome proliferator-activated receptors (PPAR) and insulin sensitivity (Palomer et al., 2018).

\section{Action mechanism of PUFA}

Insulin resistance (IR) is a metabolic disorder that disrupts the ability of peripheral tissues - as skeletal muscle -, adipose tissue, and hepatic tissue, to use insulin, thus limiting peripheral glucose use. This condition leads to increased hepatic glucose production and hyperinsulinemia resulting from pancreatic $\beta$-cell dysfunction, contributing to the development of diabetes (Berlanga-Acosta et al., 2020).

A classical pathway for IR is defective signaling of PIK3/AKT pathway, that in insulin presence is responsible for the translocation of Glut4 to the membrane, thus promoting glucose uptake. In type 2 diabetes, this pathway is blocked, especially when there are changes in the downstream proteins (Zhang, Liu, H., \& Liu, J, 2019). 
A study based on the treatment of diabetic animals with Perila oil, with mostly PUFA in its composition, observed that the treatment was responsible for raising the expression of key proteins in the PI3K/AKT signaling pathway. The expression of IRS-1/p-IRS-1, PI3K and p-AKT/AKT were increased in the oil-treated group compared with untreated diabetic animals. Moreover, the oil also increased AS160, p-AS160, and Glut4 expression, showing that it also alters glucose metabolism by transporting it (Wang et al., 2020).

Among the PUFA with the ability to improve IR cited in the literature, there is $\omega-3$ (omega), which is an essential fatty acid and it is not produced by the body, being from flaxseed, walnut, and fish (Kaur et al., 2014). The treatment of mice with a different proportion of $\omega-3 / \omega-6$ (low, medium and high) in their diet showed that the high concentration of $\omega-3$ was responsible for preventing the metabolic syndrome, regulating the mTORC1 pathway (complex 1 of mechanistic target protein of rapamycin) to increase mitochondrial function, in addition to regulating the tricarboxylic acid pathway, reducing glycemic indexes and increasing the concentration of serum insulin in these animals (Liu et al., 2020).

Conservation of mitochondrial activity is essential to maintain energy production in organism cells, however in metabolic disorders - as diabetes -, the mitochondrial function is significantly altered and it is associated with increased oxidative stress and cell death. Currently, the substances that have increased mitochondrial function are PUFA epoxides, derived from the CYP-sEH (cytochrome P450 enzymes - soluble epoxide hydrolase) metabolism pathway. These epoxides were also able to increase insulin secretion in the pancreatic islets of mice, so the use of PUFA or their metabolites in the first stages of IR may have a potential in delaying the development of insulin resistance to type 2 diabetes (Santos \& Fleming, 2020).

\section{Monounsaturated Fatty Acid in the diabetic diet}

The intake of fatty foods is related to the incidence of type 2 diabetes mellitus, however the action of these foods varies greatly with the types of fatty acids found in the diet, since some types of fat are harmful and others are beneficial. Monounsaturated and polyunsaturated fatty acids have been showing to have positive effects in diabetes mellitus (Mirmiran $e t$ al., 2018).

Among the studies that address antidiabetic actions of fatty acids, the great emphasis goes to those involving MUFA. A work of demonstrated the hypoglycemic effect of MUFA and elucidated one of their action mechanisms. When treating Wistar rats - previously induced to type 2 diabetes - with fish oil rich in MUFA for 12 weeks, this was responsible for decreasing the levels of glucose and fasting plasma as well as for improving insulin sensitivity and glucose tolerance, demonstrating its anti-hyperglycemic effect. They demonstrated fish oil rich in MUFA reduced the incidence of hyperglycemia without increasing plasma insulin levels, with results similar to the group treated with metformin, an insulin-sensitizing agent (Keapai et al., 2016).

The type of MUFA and its proportion, present in foods such as olive oil, oilseeds, and dairy products, are decisive in relation to the body's response to the intake of these foods. Study suggests that total n -3 fatty acids in the diet may be protective against insulin resistance and that SFA may promote insulin resistance, and consequently the action of SFA may contribute to the development of diabetes (Paquet et al., 2014).

These studies demonstrate the significance of considering the nature and the quality of the fat consumed, since both factors influence the development and/or prevention of insulin resistance.

\section{Fatty acids action on satiety}

The imbalance of satiety hormones are also factors associated with the development of type 2 diabetes, among them adiponectin and lepithin, derived from adipocytes, have a significance role in the modulation of lipid and glucose metabolisms (Rabe, Lehrke, Parhofer, \& Broedl, 2008). 
Adiponectin is an adipokine expressed exclusively in adipose tissue and its expression decreases with increasing adiposity. It acts as an insulin sensitizer by the activation of AMPK, which stimulates energy production from the oxidation of fatty acids and increases glucose uptake via the GLUT4 glucose transporter (Jaganathan et al., 2018).

Leptin, a protein hormone related to energy reserve, has its levels increased in obesity and decreased during fasting. It acts as an anti-obesity hormone, since it regulates food intake via control of the hypothalamus, increases energy expenditure, and regulates glucose homeostasis, stimulating PI3K signaling (Rabe et al., 2008).

Considering that adipocytokines can increase insulin sensitivity, studies have shown that high levels of adiponectin in the circulation prevent diabetes and that their plasma concentration is lower in type 2 diabetes patients than in healthy individuals (Jaganathan et al., 2018).

Studies using treatments containing MUFA in their composition, such as that by Keapai et al. (2016), demonstrate that these fatty acids lead to the reversal of the plasma levels of these hormones, increasing the levels of adiponectin and decreasing leptin in diabetic animals.

\section{Polyunsaturated fatty acids and nutritional therapy}

Recent studies have found strong evidence on the beneficial effects of dietary polyunsaturated fatty acids, mostly related to linoleic acid (omega 6) and cardiovascular health. However, the relationship between PUFA intake and type 2 diabetes has not been completely understood yet (Schwab et al., 2014; Uusitupa et al., 2013).

A research carried out by Zong et al. (2019), intended to associate PUFA (linoleic and araquidonic acids) intake to risk of developing type 2 diabetes. For that, the authors analyzed three prospective cohort studies of the United States with men and women, aged from 30 to 75 years old at the time of the recruitment. The "Nurses' Health Study (NHS; 1980-2012)," "NHSII" (1991-2013), and "Health Professionals Follow-Up Study (HPFS; 1986-2012)" studies were followed. Biannual surveys containing questions about lifestyle, health-related behaviors, and medical histories were used during the follow-up. All participants, in all of the three studies answered validated food-frequency questionnaires in order to evaluate the dietary intake of PUFA every four years. If a participant reported a confirmed diagnosis of type 2 diabetes, a supplementary questionnaire on diagnosis date and tests, symptoms, and hypoglycemic therapy was mailed.

After a careful analysis of the results, Zong et al. found evidence that a higher intake of linoleic acid is associated with a lower risk of developing type 2 diabetes, mainly when carbohydrates, trans fat, and saturated fatty acids were replaced by PUFA in an isocaloric substitution model (Zong et al., 2019).

In 2019, the United Kingdom Scientific Advisory Committee on Nutrition (SACN), published a report containing a qualitative review of 46 randomized clinical trials and prospective cohort studies. The Committee has found solid evidence of improvement in glycemic control and reduction of the risk of cardiovascular events when saturated fatty acids intake is replaced by PUFA intake. Although, further studies are necessary on issues regarding daily intake according to age and sex in a larger proportion of the population (Lenighan et al., 2019).

The eating habits of type 2 diabetic patients are broadly discussed on scientific papers, due to the straight relationship between quality and quantity of the diet and the emergence of the disease. In 2018, it was published in the respectful American Journal of Nutrition, the Diabetes and Egg "DIABEGG Study" conducted by Fuller et al. (Fuller et al., 2018).

A randomized weight-loss controlled clinical trial enrolled 128 prediabetes or diabetic subjects and assessed the effects of a dietary intervention during a three-month follow-up. It was prescribed an energy intake restriction and an either high (12 eggs/weeks) or low ( 2 eggs/weeks) diet. After three months, an isocaloric diet was prescribed, but both groups continued the already stablished egg intake. Anthropometric and biochemical parameters were assessed for the nine months that followed, completing a 12-month follow-up. At the end of the study, the authors have found that a high-egg diet was not 
significantly associated to an increase on cardiovascular risk, inflammatory and oxidative stress biomarkers nor blood sugar levels. Therefore, it is suggested that regular consumption of eggs, food rich in saturated fatty acids, is safe and it could be added to the diet of type 2 diabetes patients without adverse effects on health (Fuller et al., 2018).

A strong relationship between diabetes and oxidative stress is well-known and it is also reported in the literature. Hyperglycemia is associated to the formation of free radicals and protein glycation, which will further lead to cardiovascular damage. Nevertheless, the mechanisms related to hyperglycemia, oxidative stress, and disorders of blood vessels are yet to be fully understood (Rosca et al., 2012; Shah \& Brownlee, 2016).

Physical activity is highly recommended for type 2 diabetes patients. It may help controlling blood sugar levels and promote a faster weight loss. Notably, intense exercise training increases the production of free radicals too (Fox et al., 2015; Look AHEAD Research Group et al., 2013).

Fayh et al. (2018) suggested that inflammatory and oxidative stress biomarkers would be reduced in type 2 diabetes patients eating a PUFA rich diet and practicing intense exercise. For that, men and women were enrolled to an eight-week randomized double-blind placebo study. Participants allocated into the treatment group received n-3 PUFA (capsules containing $180 \mathrm{mg}$ of eicosapentaenoic acid, $120 \mathrm{mg}$ of docosahexaenoic, and $2 \mathrm{mg}$ of vitamin E) and placebo group, gelatin capsules. All subjects consumed the capsule three times a day. Both groups were enrolled in guided physical activities of the same intensity. The authors concluded that there were none significant changes on biomarkers levels. One of the study limitations - which might have contributed to the non-significant findings - according to the authors, is the small sized sample and short period of intervention. Therefore, further studies are necessary (Fayh et al., 2018).

Most studies show a duality on the benefits and impairments of fatty acids and diabetes. A cross-sectional study, conducted on a middle-aged dutch population $(n=5,675)$, evaluated the intake of monounsaturated, polyunsaturated and trans fatty acids and its food sources and markers of type 2 diabetes risk. The results suggested that the relationship between intake of fatty acids and biomarkers of insulin resistance may be related to the dietary source of fatty acids. Notably, fatty acids from meat were associated with insulin resistance, and fatty acids from dairy and vegetable sources were not (Wanders et al., 2017).

\section{Final Considerations}

Considering all findings presented in this review paper, it is becoming increasingly clear the important role that free fatty acids play on the prevention of metabolic diseases and/or its supporting role on nutritional therapy of diabetic patients. Experimental studies and clinical trials have found strong evidence that a reduction in the intake of saturated fatty acids and its replacement for food with MUFA and PUFA could reduce cardiovascular risk and improve glycemic control. Besides that, the food source of these fatty acids should be considered, vegetable and dairy sources should be a priority. The mechanism involved in MUFA biological activity is related to AMPK activation, modulation of satiety hormones, and anti-inflammatory cytokines, which preserves the quality of the signal transduction on the insulin pathway, avoiding the development of resistance to the hormone itself. Furthermore, PUFA increase the expression of key-proteins on the pathway AKT/PI3K, it also enhances GLUT 4 sensitivity and preserves mitochondrial activity, thus delaying the development of diabetes.

Finally, we believe that this study paves the way for the need for a concise understanding of the mechanism of action of MUFA and PUFA in insulin signaling, inflammation and their roles in the diet, yet poorly explored. Furthermore, considering the promising findings in the area and the importance of functional foods in the context of public health, we emphasize that free fatty acids should be considered as a significant part of the nutritional therapy plan for obese and/or diabetic patients. 


\section{Acknowledgments}

The authors acknowledge the financial support from Federal University of Alfenas (Unifal-MG), Minas Gerais Research Foundation (FAPEMIG) (grants APQ00637-16), National Council for Scientific and Technological Development (CNPq - Project 400865/2019-0) and Coordination for the Improvement of Higher Education Personnel - Brazil (CAPES Finance Code 001).

\section{References}

American Diabetes Association, A. D. (2020). Standards of Medical Care in Diabetes-2020 Abridged for Primary Care Providers. Clinical Diabetes, 38(1), 10-38. https://doi.org/10.2337/cd20-as01

Baynes, H. W., Mideksa, S., \& Ambachew, S. (2018). The role of polyunsaturated fatty acids (n-3 PUFAs) on the pancreatic $\beta$-cells and insulin action. Adipocyte, 7(2), 81-87. https://doi.org/10.1080/21623945.2018.1443662

Berlanga-Acosta, J., Mendoza-Marí, Y., Rodríguez-Rodríguez, N., García del Barco Herrera, D., García-Ojalvo, A., Fernández-Mayola, M., Guillén-Nieto, G., \& Valdés-Sosa, P. A. (2020). Burn injury insulin resistance and central nervous system complications: A review. Burns Open, 4(2), 41-52. https://doi.org/10.1016/j.burnso.2020.02.001

Cagen, L. M., Deng, X., Wilcox, H. G., Park, E. A., Raghow, R., \& Elam, M. B. (2005). Insulin activates the rat sterol-regulatory-element-binding protein 1c (SREBP-1c) promoter through the combinatorial actions of SREBP, LXR, Sp-1 and NF-Y cis-acting elements. Biochemical Journal, 385(Pt 1), 207-216. https://doi.org/10.1042/BJ20040162

Chen, L., Gnanaraj, C., Arulselvan, P., El-Seedi, H., \& Teng, H. (2019). A review on advanced microencapsulation technology to enhance bioavailability of phenolic compounds: Based on its activity in the treatment of Type 2 Diabetes. Trends in Food Science \& Technology, 85, 149-162. https://doi.org/10.1016/j.tifs.2018.11.026

Chen, L., Magliano, D. J., \& Zimmet, P. Z. (2011). The worldwide epidemiology of type 2 diabetes mellitus-Present and future perspectives. Nature Reviews. Endocrinology, 8(4), 228-236. https://doi.org/10.1038/nrendo.2011.183

Erkkilä, A. T., Lichtenstein, A. H., Mozaffarian, D., \& Herrington, D. M. (2004). Fish intake is associated with a reduced progression of coronary artery atherosclerosis in postmenopausal women with coronary artery disease. The American Journal of Clinical Nutrition, 80(3), 626-632. https://doi.org/10.1093/ajcn/80.3.626

Fayh, A. P. T., Borges, K., Cunha, G. S., Krause, M., Rocha, R., de Bittencourt, P. I. H., Moreira, J. C. F., Friedman, R., da Silva Rossato, J., Fernandes, J. R., \& Reischak-Oliveira, A. (2018). Effects of n-3 fatty acids and exercise on oxidative stress parameters in type 2 diabetic: A randomized clinical trial. Journal of the International Society of Sports Nutrition, 15(1), 18. https://doi.org/10.1186/s12970-018-0222-2

Fox, C. S., Golden, S. H., Anderson, C., Bray, G. A., Burke, L. E., de Boer, I. H., Deedwania, P., Eckel, R. H., Ershow, A. G., Fradkin, J., Inzucchi, S. E., Kosiborod, M., Nelson, R. G., Patel, M. J., Pignone, M., Quinn, L., Schauer, P. R., Selvin, E., \& Vafiadis, D. K. (2015). Update on Prevention of Cardiovascular Disease in Adults With Type 2 Diabetes Mellitus in Light of Recent Evidence: A Scientific Statement From the American Heart Association and the American Diabetes Association. Diabetes Care, 38(9), 1777-1803. https://doi.org/10.2337/dci15-0012

Fuller, N. R., Sainsbury, A., Caterson, I. D., Denyer, G., Fong, M., Gerofi, J., Leung, C., Lau, N. S., Williams, K. H., Januszewski, A. S., Jenkins, A. J., \& Markovic, T. P. (2018). Effect of a high-egg diet on cardiometabolic risk factors in people with type 2 diabetes: The Diabetes and Egg (DIABEGG) Studyrandomized weight-loss and follow-up phase. The American Journal of Clinical Nutrition, 107(6), 921-931. https://doi.org/10.1093/ajcn/nqy048

Huang, S., \& Czech, M. P. (2007). The GLUT4 glucose transporter. Cell Metabolism, 5(4), 237-252. https://doi.org/10.1016/j.cmet.2007.03.006

Jaganathan, R., Ravindran, R., \& Dhanasekaran, S. (2018). Emerging Role of Adipocytokines in Type 2 Diabetes as Mediators of Insulin Resistance and Cardiovascular Disease. Canadian Journal of Diabetes, 42(4), 446-456.e1. https://doi.org/10.1016/j.jcjd.2017.10.040

Kaur, N., Chugh, V., \& Gupta, A. K. (2014). Essential fatty acids as functional components of foods- a review. Journal of Food Science and Technology, 51(10), 2289-2303. https://doi.org/10.1007/s13197-012-0677-0

Keapai, W., Apichai, S., Amornlerdpison, D., \& Lailerd, N. (2016). Evaluation of fish oil-rich in MUFAs for anti-diabetic and anti-inflammation potential in experimental type 2 diabetic rats. The Korean Journal of Physiology \& Pharmacology: Official Journal of the Korean Physiological Society and the Korean Society of Pharmacology, 20(6), 581-593. https://doi.org/10.4196/kjpp.2016.20.6.581

Lenighan, Y. M., McNulty, B. A., \& Roche, H. M. (2019). Dietary fat composition: Replacement of saturated fatty acids with PUFA as a public health strategy, with an emphasis on $\alpha$-linolenic acid. Proceedings of the Nutrition Society, 78(02), 234-245. https://doi.org/10.1017/S0029665118002793

Liu, R., Chen, L., Wang, Y., Zhang, G., Cheng, Y., Feng, Z., Bai, X., \& Liu, J. (2020). High ratio of $\omega-3 / \omega-6$ polyunsaturated fatty acids targets mTORC1 to prevent high-fat diet-induced metabolic syndrome and mitochondrial dysfunction in mice. The Journal of Nutritional Biochemistry, 79, 108330. https://doi.org/10.1016/j.jnutbio.2019.108330

Look AHEAD Research Group, Wing, R. R., Bolin, P., Brancati, F. L., Bray, G. A., Clark, J. M., Coday, M., Crow, R. S., Curtis, J. M., Egan, C. M., Espeland, M. A., Evans, M., Foreyt, J. P., Ghazarian, S., Gregg, E. W., Harrison, B., Hazuda, H. P., Hill, J. O., Horton, E. S., ... Yanovski, S. Z. (2013). Cardiovascular effects of intensive lifestyle intervention in type 2 diabetes. The New England Journal of Medicine, 369(2), 145-154. https://doi.org/10.1056/NEJMoa1212914 
Mirmiran, P., Esfandyari, S., Moghadam, S. K., Bahadoran, Z., \& Azizi, F. (2018). Fatty acid quality and quantity of diet and risk of type 2 diabetes in adults: Tehran Lipid and Glucose Study. Journal of Diabetes and Its Complications, 32(7), 655-659. https://doi.org/10.1016/j.jdiacomp.2018.05.003

Palomer, X., Pizarro-Delgado, J., Barroso, E., \& Vázquez-Carrera, M. (2018). Palmitic and Oleic Acid: The Yin and Yang of Fatty Acids in Type 2 Diabetes Mellitus. Trends in Endocrinology and Metabolism: TEM, 29(3), 178-190. https://doi.org/10.1016/j.tem.2017.11.009

Paquet, C., Propsting, S. L., \& Daniel, M. (2014). Total n-3 fatty acid and SFA intakes in relation to insulin resistance in a Canadian First Nation at risk for the development of type 2 diabetes. Public Health Nutrition, 17(6), 1337-1341. https://doi.org/10.1017/S1368980013000542

Rabe, K., Lehrke, M., Parhofer, K. G., \& Broedl, U. C. (2008). Adipokines and insulin resistance. Molecular Medicine (Cambridge, Mass.), 14(11-12), 741751. https://doi.org/10.2119/2008-00058.

Rosca, M. G., Vazquez, E. J., Chen, Q., Kerner, J., Kern, T. S., \& Hoppel, C. L. (2012). Oxidation of Fatty Acids Is the Source of Increased Mitochondrial Reactive Oxygen Species Production in Kidney Cortical Tubules in Early Diabetes. Diabetes, 61(8), 2074-2083. https://doi.org/10.2337/db11-1437

Saeedi, P., Petersohn, I., Salpea, P., Malanda, B., Karuranga, S., Unwin, N., Colagiuri, S., Guariguata, L., Motala, A. A., Ogurtsova, K., Shaw, J. E., Bright, D., Williams, R., \& IDF Diabetes Atlas Committee. (2019). Global and regional diabetes prevalence estimates for 2019 and projections for 2030 and 2045 : Results from the International Diabetes Federation Diabetes Atlas, 9th edition. Diabetes Research and Clinical Practice, 157, 107843. https://doi.org/10.1016/j.diabres.2019.107843

Salas-Salvadó, J., Bulló, M., Estruch, R., Ros, E., Covas, M.-I., Ibarrola-Jurado, N., Corella, D., Arós, F., Gómez-Gracia, E., Ruiz-Gutiérrez, V., Romaguera, D., Lapetra, J., Lamuela-Raventós, R. M., Serra-Majem, L., Pintó, X., Basora, J., Muñoz, M. A., Sorlí, J. V., \& Martínez-González, M. A. (2014). Prevention of diabetes with Mediterranean diets: A subgroup analysis of a randomized trial. Annals of Internal Medicine, 160(1), 1-10. https://doi.org/10.7326/M13-1725

Schwab, U., Lauritzen, L., Tholstrup, T., Haldorsson, T. I., Riserus, U., Uusitupa, M., \& Becker, W. (2014). Effect of the amount and type of dietary fat on cardiometabolic risk factors and risk of developing type 2 diabetes, cardiovascular diseases, and cancer: A systematic review. Food \& Nutrition Research, 58 . https://doi.org/10.3402/fnr.v58.25145

Santos, L. R. B., \& Fleming, I. (2020). Role of cytochrome P450-derived, polyunsaturated fatty acid mediators in diabetes and the metabolic syndrome. Prostaglandins \& Other Lipid Mediators, 148, 106407. https://doi.org/10.1016/j.prostaglandins.2019.106407

Shah, M. S., \& Brownlee, M. (2016). Molecular and Cellular Mechanisms of Cardiovascular Disorders in Diabetes. Circulation research, 118(11), 18081829. https://doi.org/10.1161/CIRCRESAHA.116.306923

Tan, E., Khoo, J., Gani, L. U., Malakar, R. D., Tay, T. L., Tirukonda, P. S., Kam, J. W., Tin, A. S., \& Tang, T. Y. (2019). Effect of multidisciplinary intensive targeted care in improving diabetes mellitus outcomes: A randomized controlled pilot study - the Integrated Diabetes Education, Awareness and Lifestyle modification in Singapore (IDEALS) Program. Trials, 20(1), 549. https://doi.org/10.1186/s13063-019-3601-3

Uusitupa, M., Hermansen, K., Savolainen, M. J., Schwab, U., Kolehmainen, M., Brader, L., Mortensen, L. S., Cloetens, L., Johansson-Persson, A., Onning, G., Landin-Olsson, M., Herzig, K.-H., Hukkanen, J., Rosqvist, F., Iggman, D., Paananen, J., Pulkki, K. J., Siloaho, M., Dragsted, L., \& Akesson, B. (2013). Effects of an isocaloric healthy Nordic diet on insulin sensitivity, lipid profile and inflammation markers in metabolic syndrome-A randomized study (SYSDIET). Journal of Internal Medicine, 274(1), 52-66. https://doi.org/10.1111/joim.12044

Wanders, A. J., Alssema, M., de Koning, E. J. P., le Cessie, S., de Vries, J. H., Zock, P. L., Rosendaal, F. R., Heijer, M. den, \& de Mutsert, R. (2017). Fatty acid intake and its dietary sources in relation with markers of type 2 diabetes risk: The NEO study. European Journal of Clinical Nutrition, 71(2), 245-251. https://doi.org/10.1038/ejcn.2016.204

Wang, J., He, Y., Yu, D., Jin, L., Gong, X., \& Zhang, B. (2020). Perilla oil regulates intestinal microbiota and alleviates insulin resistance through the PI3K/AKT signaling pathway in type-2 diabetic KKAy mice. Food and Chemical Toxicology: An International Journal Published for the British Industrial Biological Research Association, 135, 110965. https://doi.org/10.1016/j.fct.2019.110965

World Health Assembly. (2013). Follow-up to the political declaration of the high-level meeting of the general assembly on the prevention and control of noncommunicable diseases. WHA. https://apps.who.int/iris/bitstream/handle/10665/150161/A66_R10-en.pdf?sequence=1\&isAllowed=y.

World Health Organization. (2018). Noncommunicable diseases: Country profiles 2018. World Health Organization. https://www.who.int/publications-detailredirect/ncd-country-profiles-2018

World Health Organization. (2020). WHO Integrated chronic disease prevention and control. WHO - World Health Organization; World Health Organization. https://www.who.int/chp/about/integrated_cd/en/

Zhang, Z., Liu, H., \& Liu, J. (2019). Akt activation: A potential strategy to ameliorate insulin resistance. Diabetes Research and Clinical Practice, 156, 107092. https://doi.org/10.1016/j.diabres.2017.10.004

Zierath, J. R. (2019). Major Advances and Discoveries in Diabetes-2019 in Review. Current Diabetes Reports, 19(11). https://doi.org/10.1007/s11892-019$1255-\mathrm{x}$

Zong, G., Liu, G., Willett, W. C., Wanders, A. J., Alssema, M., Zock, P. L., Hu, F. B., \& Sun, Q. (2019). Associations Between Linoleic Acid Intake and Incident Type 2 Diabetes Among U.S. Men and Women. Diabetes Care, 42(8), 1406-1413. https://doi.org/10.2337/dc19-0412 